\section{The erosive potential of candy sprays}

\author{
D. L. Gambon, ${ }^{1}$ H. S. Brand ${ }^{2}$ and A. V. Nieuw Amerongen ${ }^{3}$
}

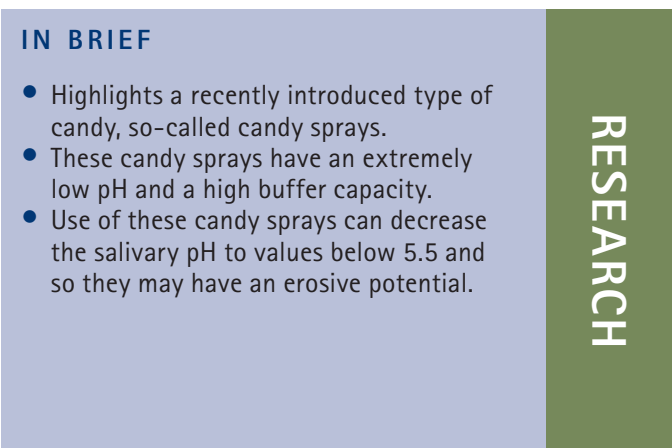

\begin{abstract}
Objective To determine the erosive potential of seven different commercially available candy sprays in vitro and in vivo. Material and methods The erosive potential was determined in vitro by measuring the $\mathrm{pH}$ and neutralisable acidity. The salivary $\mathrm{pH}$ and flow rate were measured in healthy volunteers after administration of a single dose of candy spray. Results Candy sprays have an extremely low pH (1.9-2.3) and a neutralisable acidity varying between 0.8-1.6 ml of 0.25M NaOH. In vivo, candy sprays induced a short-term 3.0 to 5.8 -fold increase in salivary flow rate with a concomitant drop in salivary $\mathrm{pH}$ to values between 4.4 and 5.8. Conclusion All candy sprays tested have an erosive potential. This information is of use for clinicians counselling juvenile patients with dental erosion.
\end{abstract}

\section{INTRODUCTION}

Dental erosion has been defined as the physical result of a pathologic, chronic localised loss of dental hard tissue that is chemically etched away from the tooth surface by acid and/or chelation without bacterial involvement. ${ }^{1}$ In the United Kingdom, the prevalence of dental erosion is high in children and young adolescents and the prevalence still seems to be increasing..$^{2-14}$ Although the aetiology of dental erosion is multifactorial, it is assumed that dietary sources of acids are the major risk factor in this age group. Several studies found an association between the presence of dental erosion and a high level of consumption of cola-type and other flavoured carbonated beverages. ${ }^{7,9,12,13,15-17}$ Many soft drinks contain phosphoric, citric and other acids as ingredients, and their $\mathrm{pH}$ is often less than 4.0. ${ }^{18-20}$

Solid acidic candies also contain organic acids like citric acid, lactic and/or malic

\footnotetext{
*Bambodino Pediatric Dental Clinic, Meerum Terwogtlaan 133, 3056 PP Rotterdam, The Netherlands; 2,3 Department of Dental Basic Sciences, Section of Oral Biochemistry, Academic Centre for Dentistry Amsterdam (ACTA), v.d.Boechorststraat 7, 1081 BT Amsterdam, The Netherlands

${ }^{*}$ Correspondence to: Dr Dien L. Gambon

Tel: +31 10433 4243; Fax: +31 104113957

Email:gambon@bambodino.nl
}

\section{Online article number E20}

Refereed Paper - Accepted 18 December 2008

DOI: $10.1038 /$ sj.bdj.2009.378

${ }^{\circ}$ British Dental Journal 2009; 206: E20

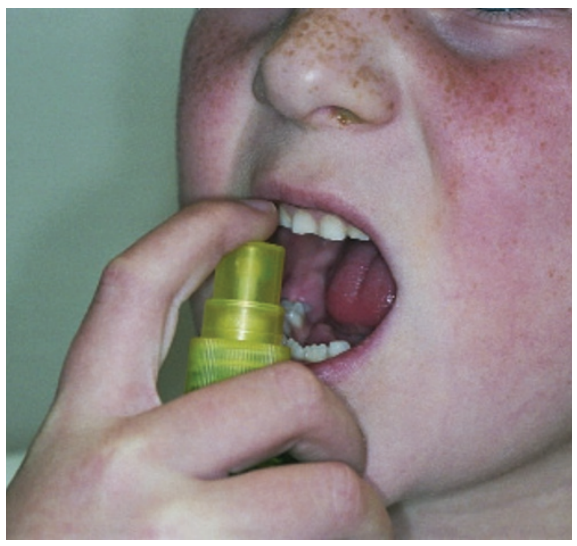

Fig. 1 A child using a candy spray

acids to develop the characteristic sour taste. Homogenised candies dissolved in water decrease the $\mathrm{pH}$ to values below $4 .{ }^{21}$ In vivo studies have shown that sucking acidic candies decreases the salivary $\mathrm{pH}$ to 4.5.22,23 Acidic candies were capable of softening enamel both in vitro and in situ..$^{24,25}$ Taken together, this suggests that (excessive) consumption of acidic candies can contribute to the development of dental erosion, especially in individuals with low salivary flow rates and low salivary buffer capacity. ${ }^{25}$

A recently introduced type of acidic candy is the so-called candy spray, which has to be sprayed directly into the mouth (Fig. 1). This gives an immediate sour-fresh taste and tingling feeling on the tongue. Candy sprays are very popular among primary school children. In the Netherlands,

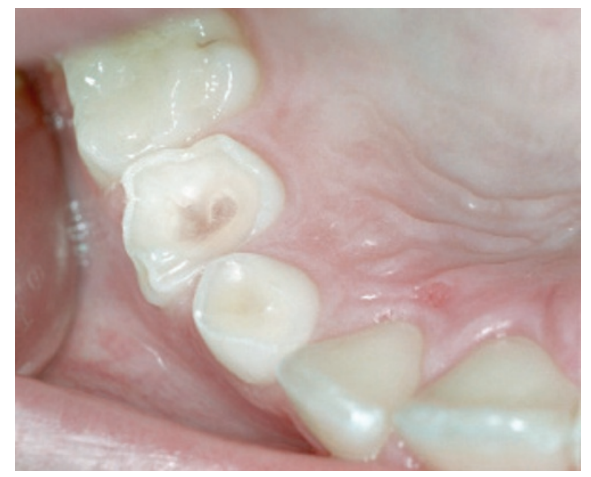

Fig. 2 Erosion of occlusal surfaces in a nineyear-old girl with a history of excessive use of candy spray

$31 \%$ of children between four and eight years old and 58\% of children between nine and 12 years old reported they had used candy sprays. ${ }^{26}$ In the same study, a nineyear-old girl was presented with severe erosion of the occlusal surfaces attributed to excessive use of candy spray, indicating that candy sprays have a potential risk for dental erosion (Fig. 2). Since several types and tastes of candy sprays are available in the United Kingdom, the aim of this study was to compare the erosive potential of a number of commercially available candy sprays both in vitro and in vivo.

\section{METHODS}

Seven candy sprays, widely available to the general public, were chosen for this study (Table 1, Fig. 3). First, the $\mathrm{pH}$ of each candy spray was determined with 
an electronic pH meter (PHM 240 Sentron 1001, Radiometer, Copenhagen, Denmark), calibrated each morning with reference buffers of pH 4.00 and pH 7.00 (SigmaAldrich, St. Louis, USA). Neutralisable acidity ('buffer capacity') of the candy sprays was determined by stepwise addition of $0.1 \mathrm{ml} 0.25 \mathrm{M} \mathrm{NaOH}$ to $1 \mathrm{ml}$ of candy spray till a $\mathrm{pH}>7$ was obtained. The volume of a single dose of each candy spray was determined gravimetrically (assuming $1 \mathrm{~g}=1 \mathrm{ml}$ ).

The effect of candy sprays on saliva secretion rate and $\mathrm{pH}$ were investigated in three healthy volunteers, $53 \pm 9$ years of age, fully dentate ( $\geq 28$ teeth), without active caries and not suffering from taste abnormalities or xerostomia. The volunteers were instructed to abstain from smoking, eating, drinking and tooth brushing at least $1 \mathrm{~h}$ before the experiments. ${ }^{27}$

First, unstimulated whole saliva was collected for five minutes. ${ }^{28} \mathrm{Next}$, in random order a single dose of each candy spray was administered on the tongue and whole saliva was collected in one minute intervals for a total period of five minutes. The saliva secretion rates were determined gravimetrically (assuming $1 \mathrm{~g}=1$ $\mathrm{ml}$ ) and the salivary $\mathrm{pH}$ was measured as described above.

\section{RESULTS}

The $\mathrm{pH}$ values of the candy sprays were very low and ranged from 1.90-2.28 (Table 1). The results for the neutralisable acidity are presented in Figure 4. Most candy sprays tested had a neutralisable acidity between $0.8-1.0 \mathrm{ml}$ of $0.25 \mathrm{M} \mathrm{NaOH}$, but the 'Candy spray strawberry' and the 'Fruitti squirt strawberry' had an almost two-fold higher neutralisable acidity than the other candy sprays.

The volume of a single dose is comparable for all candy sprays (range 132-147 $\mu$ l), with the exception of 'Magic spray strawberry' which produces a smaller volume (95 $\mu l$, see Table 1). Intraoral administration of a single dose of candy spray induced a transient 3.0 to 5.8-fold increase in salivary flow rate (Fig. 5). The highest salivary flow rates were observed after use of the 'Candy spray strawberry' and the 'Fruitti squirt strawberry', the lowest after the 'Magic spray strawberry'. Concomitantly, the salivary $\mathrm{pH}$ dropped instantly to values between 4.4 and 5.8 (Fig. 6), and for five

\begin{tabular}{|c|c|c|c|c|}
\hline Product & $\mathrm{pH}$ & $\begin{array}{l}\text { Single } \\
\text { dose }(\mu l)\end{array}$ & Acid & Distributor \\
\hline Candy spray strawberry & 1.99 & 145 & citric acid & Starsweets International \\
\hline Fruitti squirt strawberry & 2.00 & 132 & citric acid & Starsweets International \\
\hline Magic spray strawberry & 2.28 & 95 & citric acid & Pemi Trade \\
\hline Mega mouth spray strawberry & 1.92 & 146 & citric acid & Topps International Ltd \\
\hline Mega mouth spray orange & 1.90 & 146 & citric acid & Topps International Ltd \\
\hline Mega mouth spray blackcurrent & 1.92 & 147 & citric acid & Topps International Ltd \\
\hline Mega mouth spray apple & 1.91 & 137 & citric acid & Topps International Ltd \\
\hline
\end{tabular}

of the candy sprays the values were below $\mathrm{pH}$ 5.5. The strongest decrease in salivary $\mathrm{pH}$ was observed using the 'Candy spray strawberry' ( $\mathrm{pH} 4.4$ ) and the 'Fruitti squirt strawberry' (pH 4.8). For the 'Magic spray strawberry' and the 'Mega mouth spray apple', the salivary $\mathrm{pH}$ remained above $\mathrm{pH}$ 5.5. Both the salivary flow rate and the $\mathrm{pH}$ returned to normal values within 2-3 minutes (Figs 5 and 6).

\section{DISCUSSION}

The aim of this study was to compare the potential erosive effects of several candy sprays. All candy sprays tested in this study were highly acidic, indicating that they contain high levels of citric acid (Table 1). Their initial $\mathrm{pH}$ values ranged from 1.90-2.28, well below the $\mathrm{pH}$ value of 5.5 that has generally been adopted as the critical value below which hydroxyapatite may dissolve. ${ }^{29,30}$

The erosive potential does not exclusively depend on the $\mathrm{pH}$ of the candy spray, but is also strongly influenced by its neutralisable acidity ('buffer capacity') and the volume administered. The greater the neutralisable acidity of the candy spray, the longer it will take for saliva to neutralise it. ${ }^{19}$ Of the candy sprays tested, the 'Candy spray strawberry' and the 'Fruitti squirt strawberry' had a much higher neutralisable acidity than the other candy sprays (Fig. 4). After intraoral administration, these two candy sprays result in $\mathrm{pH}$ values far below 5.5 (Fig 6), indicating that this type of candy has the potential to lower the salivary $\mathrm{pH}$ considerably in vivo. This is in agreement with comparable studies showing the erosive potential of solid acidic candies. ${ }^{21-25}$ The smallest decrease in salivary $\mathrm{pH}$ in vivo was observed after

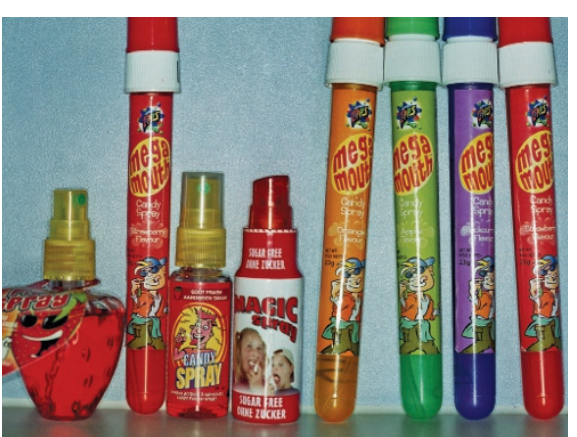

Fig. 3 The different types of candy sprays investigated in this study

administration of a single dose of 'Magic spray strawberry'. This is probably related to three factors. First, this candy spray has a higher $\mathrm{pH}$ (Table 1). Second, the amount of neuralisable acidity in 'Magic spray strawberry' is smaller (Fig. 4). Finally, the volume of a single dose of this candy spray is considerably smaller than the other candy sprays tested (Table 1 and Fig. 4).

The citric acid in the candy sprays stimulates the salivary flow immediately after they have been introduced into the mouth (Fig. 5). The buffering effects of the stimulated salivary flow may provide some protection against the erosive potential of acidic candy. ${ }^{21,22,31}$ However, citric acid is a complex organic acid. At low $\mathrm{pH}$ values, citric acid provides protons which directly attack the mineral surface. At higher $\mathrm{pH}$ levels around $\mathrm{pH}$ 7.0, the citrate anion may draw calcium away from the enamel by chelation. This means that the demineralising effect of citric acid is exceptionally great and may even continue after the $\mathrm{pH}$ at the tooth surface has increased. ${ }^{18,31,32}$

Our in vivo results are based on a single administration of candy spray to adult volunteers. However, candy sprays are frequently used by children during the 
day $^{26}$ and the volume of saliva in children is smaller than in adults. ${ }^{33,34}$ Therefore, in children a single dose of candy spray will introduce a relatively higher amount of spray in the oral cavity and thus probably an even lower salivary $\mathrm{pH}$ value. Repeated use of candy sprays may also exacerbate the erosive potential, as the longer the teeth are bathed in acid the longer the period of time when erosion can occur and the shorter the time period for remineralisation to take place. ${ }^{19,20}$

Differences seem to exist in susceptibility of deciduous and permanent dentition to erosion by low $\mathrm{pH}$ drinks and solid acidic candy. In general, erosion of enamel was greater in the deciduous tissue, especially with increased frequency of consumption. ${ }^{21,35,36}$ In combination with the reduced dimensions, this makes the deciduous dentition more susceptible to exposure to candy sprays, especially when used frequently.

\section{CONCLUSION}

In summary, candy sprays are potentially capable of causing dental erosion. Both healthcare professionals as well as consumers should be aware of this erosive potential. However, candy sprays are usually consumed by young children. In 70\% of cases, their parents were unaware that their children used this type of candy. ${ }^{26}$ Therefore, both juvenile patients and their parents should be informed that (excessive) use of candy sprays may cause dental erosion.

1. ten Cate J M, Imfeld T. Dental erosion, summary. Eur J Oral Sci 1996; 104: 241-244.

2. Al-Dlaigan $Y H$, Shaw L, Smith A. Dental erosion in a group of British 14-year-old school children. Part I: prevalence and influence of differing socioeconomic backgrounds. Br Dent J 2001; 190: 145-149.

3. Al-Malik M I, Holt R D, Bedi R. The relationship between erosion, caries and rampant caries and dietary habits in preschool children in Saudi Arabia. Int J Paediatr Dent 2001; 11: 430-439.

4. Bartlett D W, Coward PY, Nikkah C, Wilson R F. The prevalence of tooth wear in a cluster sample of adolescent schoolchildren and its relationship with potential explanatory factors. Br Dent J 1998; 184: 125-129.

5. Deery C, Wagner M L, Longbottom C, Simon R, Nugent Z J. The prevalence of dental erosion in a United States and a United Kingdom sample of adolescents. Pediatr Dent 2000; 22: 505-510.

6. Dugmore C R, Rock W P. The progression of tooth erosion in a cohort of adolescents of mixed ethnicity. Int J Paediatr Dent 2003; 13: 295-303.

7. Dugmore CR, Rock W P. A multifactorial analysis of factors associated with dental erosion. Br Dent J 2004; 196: 283-286

8. Jones S G, Nunn J H. The dental health of 3-yearold children in east Cumbria 1993. Community Dent Health 1995: 12: 161-166.

9. Millward A, Shaw L, Smith A J, Rippin J W,

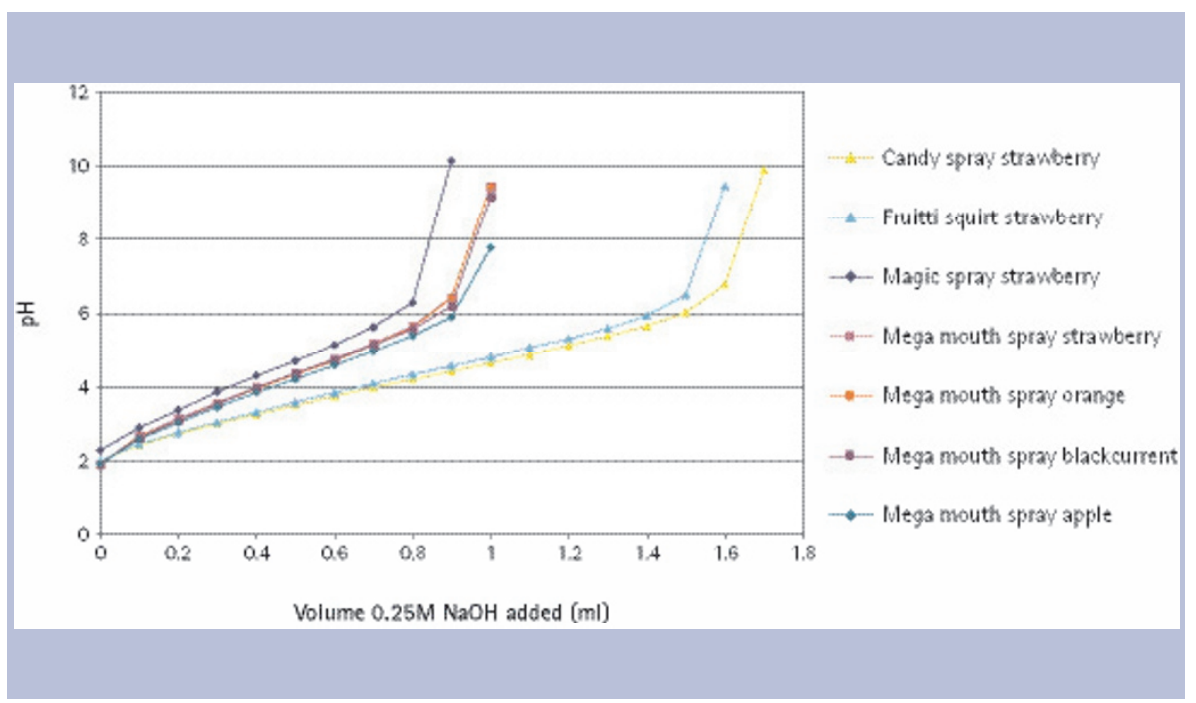

Fig. 4 Neutralisable acidity ('buffer capacity') of seven different candy sprays

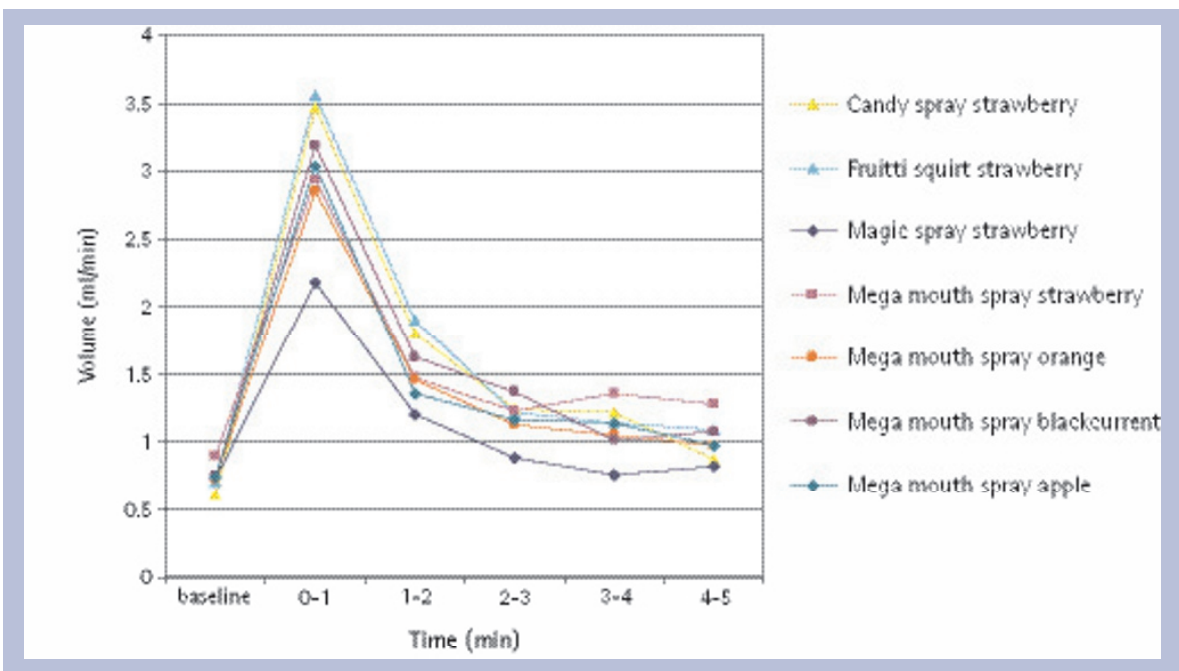

Fig. 5 Mean salivary flow rate at different time points after application of seven different candy sprays $(n=3)$

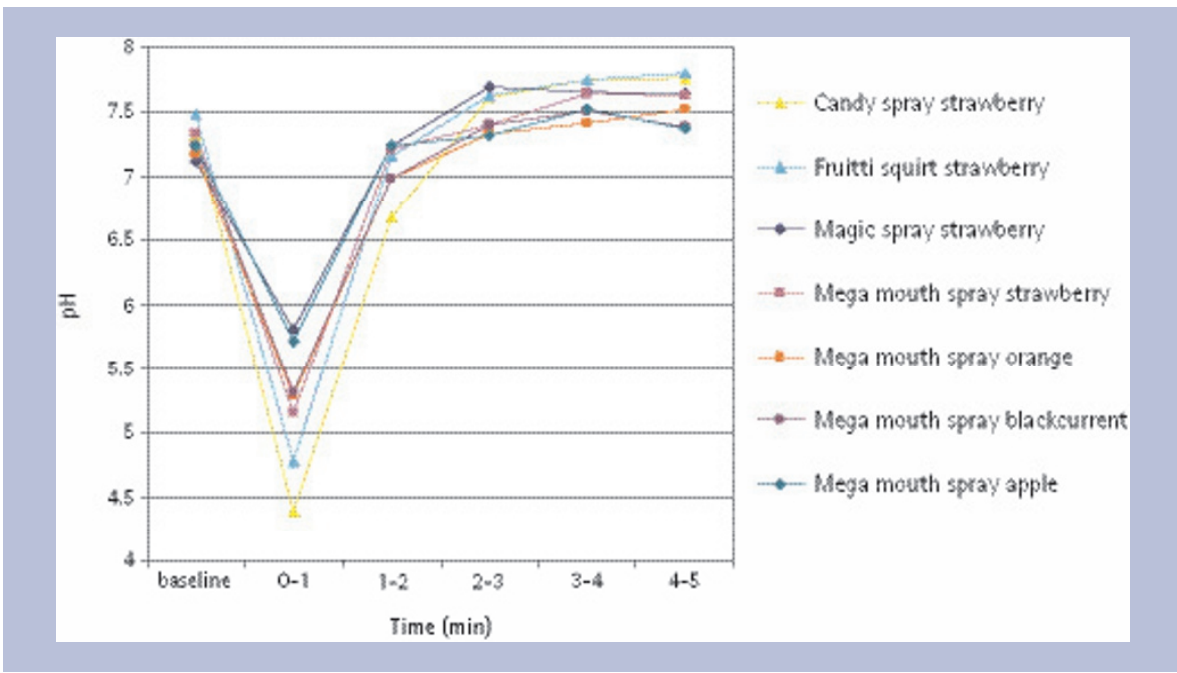

Fig. 6 Mean pH of saliva at different time points after application of seven different candy sprays $(n=3)$

Harrington E. The distribution and severity of tooth wear and the relationship between erosion and dietary constituents in a group of children. Int $J$ Paediatr Dent 1994; 4: 151-157.
10. Millward A, Shaw L, Smith A. Dental erosion in four-year-old children from differing socioeconomic backgrounds. ASDC J Dent Child 1994; 61: 263-266. 
11. Milosevic A, Young P J, Lennon M A. The prevalence of tooth wear in 14-year-old school children in Liverpool. Community Dent Health 1994; 11: 83-86.

12. Milosevic $A$, Lennon M A, Fear S C. Risk factors associated with tooth wear in teenagers: a case control study. Community Dent Health 1997; 14: 143-147.

13. Nunn J H, Gordon P H, Morris A J, Pine C M, Walke A. Dental erosion - changing prevalence? A review of British National childrens' surveys. Int J Paediatr Dent 2003; 13: 98-105.

14. Williams D, Croucher R, Marcenes W, O'Farrell M. The prevalence of dental erosion in the maxillary incisors of 14-year-old schoolchildren living in Tower Hamlets and Hackney, London, UK. Int Dent J 1999; 49: 211-216.

15. Al-Dlaigan $Y$ H, Shaw L, Smith A. Dental erosion in a group of British 14-year-old school children. Part II: influence of dietary intake. Br Dent J 2001; 190: 258-261.

16. Jensdottir T, Arnadottir IB, Thorsdottir I et al. Relationship between dental erosion, soft drink consumption, and gastroesophageal reflux among Icelanders. Clin Oral Investig 2004; 8: 91-96.

17. Johansson A K, Johansson A, Birkhed D et al. Dental erosion associated with soft-drink consumption in young Saudi men. Acta Odontol Scand 1997; 55: 390-397.

18. Järvinen V K, Rytömaa I I, Heinonen O P. Risk factors in dental erosion. J Dent Res 1990; 70: 942-947.

19. Lussi A, Jaeggi T, Zero D. The role of diet in the aetiology of dental erosion. Caries Res 2004 38(Suppl 1): 34-44.

20. Moynihan P J. Dietary advice in dental practice. Br Dent J 2002; 193: 563-568.

21. Davies R, Hunter L, Loyn T, Rees J. Sour sweets: a new type of erosive challenge. Br Dent J 2008; 204: E3.

22. Jensdottir T, Nauntofte B, Buchwald C, Bardow A Effects of sucking acidic candy on the wholemouth saliva composition. Caries Res 2005; 39: 468-474.

23. Jensdottir T, Nauntofte B, Buchwald C, Bardow A Effects of calcium on the erosive potential of acidic candies in saliva. Caries Res 2007; 41: 68-73.

24. Bibby B G, Mundorff S A. Enamel demineralization by snack foods. J Dent Res 1975; 54: 461-470.

25. Lussi A, Portman P, Burhop B. Erosion on abraded dental hard tissues by acidic lozenges: an in situ study. Clin Oral Investig 1997; 1: 191-194.

26. Gambon D L, van de Keijbus P A M, Nieuw Amerongen A V. [Candy sprays and-gels: effect on salivary flow and $\mathrm{pH}$ ]. Ned Tijdschr Tandheelkd 2006; 113: 27-32. [In Dutch].

27. Hoek G H, Brand H S, Veerman E C I, Nieuw Amerongen $\mathrm{A} V$. Toothbrushing affects the protein composition of whole saliva. Eur J Oral Sci 2002; 110: 480-481.

28. Bosch J A, Brand H S, Ligtenberg T J, Bermond
B, Hoogstraten J, Nieuw Amerongen A V. Psychological stress as a determinant of protein levels and salivary-induced aggregation of Streptococcus gordonii in human whole saliva. Psychosom Med 1996; 58: 374-382.

29. Ericsson Y. Enamel apatite solubility. Acta Odontol Scand 1949; 8(Suppl 3): 1-139.

30. Larsen M J, Pearce E I F. Saturation of human saliva with respect to calcium salts. Arch Oral Biol 2003; 48: 317-322.

31. Hunter M L, Patel R, Loyn T, Morgan M Z, Fairchild $R$, Rees J S. The effect of dilution on the in vitro erosive potential of a range of dilutable fruit drinks. Int J Paediatr Dent 2008; 18: 251-255.

32. Lussi A, Jaeggi I. Erosion - diagnosis and risk factors. Clin Oral Investig 2008; 12(Suppl 1): S5-S13.

33. Crossner C G. Salivary flow rate in children and adolescents. Swed Dent J 1984; 8: 271-276.

34. Watanabe $S$, Dawes C. Salivary flow rates and salivary film thickness in five-year-old children. J Dent Res 1990; 69: 1150-1153.

35. Hunter M L, West N X, Hughes J A, Newcombe R $G$, Addy M. Erosion of deciduous and permanent dental hard tissue in the oral environment. J Dent 2000; 28: 257-263

36. Hunter M L, West N X, Hughes J A, Newcombe R G, Addy M. Relative susceptibility of deciduous and permanent dental hard tissues to erosion by a low pH fruit drink in vitro. J Dent 2000; 28: 265-270. 